\title{
Determinants of B2B E-Commerce Adoption in Saudi Arabian Firms
}

\author{
Sabah A. Al-Somali, Roya Gholami, Ben Clegg \\ Aston University
}

\begin{abstract}
Business-to-business (B2B) electronic commerce (e-commerce) has become an increasingly important initiative among organisations. The factors affecting the adoption decisions have been well-documented but there is a paucity of empirical studies that examine the adoption of e-commerce in developing economies in the Arab world. The aim of our study is to provide insights into the salient e-commerce adoption issues by focusing on Saudi Arabian businesses. We developed a conceptual model for B2B e-commerce adoption incorporating six factors. Survey data from 450 businesses were used to test the model and hypotheses. The analysis demonstrates that, (1) when e-commerce preliminary adoption is investigated, organizational IT readiness, management support and regulatory environment emerge as the strongest factor, (2) pressure from customers may not have much effect on the preliminary adoption of e-commerce by companies, but does significantly influence on the utilisation of e-commerce by firms, and (3) Saudi Arabia has a strong ICT infrastructure for supporting e-commerce practices. Taken together, these findings on the multi-dimensionality of e-commerce adoption show that preliminary adoption and utilisation of $e$ commerce are not only different measures of $e$ commerce adoption, but also have different determinants. The implications of the findings are discussed and suggestions for future inquiry are presented.
\end{abstract}

Keywords: e-commerce adoption, Saudi Arabia, developing Arab nations, innovation diffusion.

\section{Introduction}

Technological innovations such as the Internet and the World Wide Web (WWW) have enabled many organisations to undertake transactions, share information, and collaborate across geographical boundaries and across computing platforms and networks. Indeed, the Internet and its associated technologies are the key to the survival and growth of businesses in today's competitive environment.

E-commerce is commonly defined as the sharing of business information, maintaining business relationships, and conducting business transactions by means of telecommunications networks [9].

Many studies have been conducted in advanced countries in the West to explore factors that facilitate and inhibit the adoption and diffusion of e-commerce by organisations. However, it is widely acknowledged that theories and management practices developed in the context of industrialized and developed countries in the West need to be reexamined in the context of developing countries to fit the cultural context of the recipient nation [6]. This is because issues which might seem trivial for developed countries may play an important role for e-commerce adoption in developing countries. For instance, the major issues in developing regions are slow speeds, the high prices of Internet service providers (ISPs), an insufficient regulatory environment and poor infrastructure; whereas in developed countries, the main issues are privacy and taxes [19]. Yet, it seems that there is a paucity of writing in the context of developing economies in the Arab world and the patterns of organisational adoption of e-commerce remain a largely unexplored area. Particularly, few studies have explored ecommerce growth in the high-income economies in the Arabian Gulf region [4]. This paucity of research on e-commerce adoption, exploring the factors that influence e-commerce adoption in developing Arab countries, leaves a significant gap. Thus, the present study attempts to bridge the knowledge gap in the extant literature about e-commerce adoption and diffusion in Gulf region.

To better understand the phenomena under investigation, we developed a conceptual model for B2B e-commerce adoption and we tested this model using survey data from 450 firms in the private sector. Discriminant analysis was used as a data analysis technique.

\section{Background}

This empirical study was conducted in the Saudi Arabian business environment. In fact, Saudi Arabia forms an interesting context and domain for the study. This is because economic liberalisation programmes initiated in Saudi Arabia in the 1980s have resulted in attempts at overall transformation of technology usage among Saudi industries. Despite this, prior research in Saudi Arabia has indicated that, although ICT is rapidly growing in Saudi Arabia (both PC sales and Internet growth are high), it is generally believed that e-commerce practices are not progressing at the same speed [2]. Moreover, familiarity with, and confidence in ICT among organisations has remained limited compared to other Arab countries, such as the United Arab Emirates (UAE), who share similar characteristics in 
terms of socioeconomic, commercial, and infrastructural development.

It is particularly noteworthy that there is a paucity of empirical studies on B2B e-commerce in the context of Saudi Arabia. Studies conducted up to date in the context of Saudi Arabia are found to focus on B2C e-commerce and from the consumers' perspective rather than that of $\mathrm{B} 2 \mathrm{~B}$ e-commerce or the organisational level (i.e. [5]). In fact, the outcomes from these studies are limited and they do not cover other issues that might directly influence organisational tendencies toward e-commerce adoption in Saudi Arabia. This necessitates further investigation into the factors to mitigate the adoption of B2B e-commerce, in order to give a clear evaluation of the -commerce phenomenon in Saudi Arabia. This includes evaluating organisational issues of e-commerce within organizations.

The Kingdom of Saudi Arabia is the largest and most populated of the six Gulf Cooperation Council (GCC) states in the Middle East. Saudi Arabia is the largest oil-exporting country in the world and this represented a substantial increase in the economic wealth of Saudi Arabia, placing the government in a strong fiscal position, and providing the means and opportunities to support their continued growth and investment in information and communication technology (ICT) infrastructure.

The Saudi private sector is Saudi Arabia can be divided into three categories: a) commercial, industrial, and service establishments registered in the Commercial Register; b) retail outlets and small service facilities and workshops licensed by the municipalities; c) agricultural holding and related production units. The economic problems which the Kingdom experienced in the mid 1980's, due to the unfavourable oil prices, has resulted in the Saudi government's move from being an economy almost wholly dependent on the export of oil, towards one focused on expanding the role of the private sector. Saudi Arabia is one of the fastest growing Internet markets in the Middle East and statistics show that more than $80 \%$ of Saudi industrial companies use computers and their applications [18].

\section{Organisational innovation adoption}

Adoption is defined as the "generation, development and implementation of new innovation. On the other hand, an innovation can be a new product or service, a new practice, a new structure or administrative system, or a new plan or program that is viewed as new by organisational members or the adopting unit [25]. In fact, adopting Internet technologies for e-mail, Web browsing and engaging in electronic commerce to sell or purchase goods are considered as one of the primary sources of competitive advantage and can be viewed as innovation that has enabled modern day organisations to undertake transactions, share information, collaborate across geographical boundaries and across computing platforms and networks.

Firms, like consumers, differ in their likelihood and speed to adopt new innovation. However, the process of organisational innovation is very different from adoption of innovations by individuals. In fact, organisations are found to follow a relatively stable and predictable pattern of development through a number of successive, cumulative and identifiable stages in which achievement of the first stages of development allows the organisation to gain experience to move on to the next stage of development. For example, when organisations adopt e-commerce, they are found to move from no online presence on the Web, through a static, informational presence ultimately to more sophisticated applications that enable transactional trading including online buying and payment and more importantly integrating business processes allowing most business transactions to be conducted electronically.

E-commerce adoption in this study focuses on the preliminary adoption of e-commerce and the extent to which e-commerce is being used or utilised by the firms (reflecting its maturity level or sophistication). It tests whether the organisation has attained informational e-commerce, interactive e-commerce status, a transactional trading including online payment and customer service or has integrated business processes allowing most business transactions to be conducted electronically [19].

Organisational innovations adoption has received considerable interest from scholars, industry groups and policy makers. This interest resulted in developing various theories to examine the factors that facilitate or inhibit the adoption of innovation.

Rogers's [25] innovation diffusion theory has been utilised in most of the e-commerce studies. Moreover, previous research identified factors that are important for the successful adoption of ecommerce in organisations $[3,30]$.

Tornatzky and Fleischer [31] classified into three groups the factors that influence the diffusion process, namely: (i) the technological context concerns the nature of the adopted technology and it looks at factors such as technological intensity and competence; (ii) the organisational context includes an organisation's attributes such as size, business sector, processes and resources; and (iii) the environmental context includes the industry an organisation is in, its competitors, accessibility to the resources supplied by others, and dealings with government. These factors thus form the TOE framework, which summarizes the principal determinants of innovation diffusion and has been utilised for studying different types of technological innovations. Zhu et al. [34] note that e-commerce is 
enabled by technological development of the Internet, driven by organisational factors, and influenced by environmental factors related to customers and business partners as well as competitors

Based on the TOE framework, this study has identified a variety of factors that influence firm's propensity to adopt B2B e-commerce.

\subsection{Organisational IT readiness}

Number of studies have documented that IT sophistication affects firm's ability to adopt IS. The literature suggests that information technology (IT) readiness operates on two basic components; namely, technical readiness (i.e. technological infrastructure) and personnel IT knowledge (i.e. human resources that are precursors to the adoption of information systems innovation) [33]. It is believed that, because of the lack of skill and the technical knowledge required in the development process, many organisations delay innovation adoption, and tend to wait until they have sufficient technical expertise. In fact, firm's technological predisposition is a key for firms to adopt new technologies. This leads to the following hypotheses:

Ha1: Organisational IT readiness contributes significantly (and is positively related) to the preliminary adoption of e-commerce.

$\mathrm{Ha}$ 2: Organisational IT readiness contributes significantly (and is positively related) to the utilisation of e-commerce.

\subsection{Top management support}

A widespread literature in organisational innovation adoption suggests that management support is believed to be one of the most important factors that influence the adoption of innovation. Successful innovation adoption requires support from top management to integrate the innovation into business activities and processes [32]. Broadly speaking e-commerce may be exacerbated by poor management commitment and support. Based on the above discussion, we hypothesize that:

$\mathrm{Hb1}$ : Top management support contributes significantly (and is positively related) to the preliminary adoption of e-commerce.

$\mathrm{Hb}$ 2: Management team support contributes significantly (and is positively related) to the utilisation of e-commerce.

\subsection{Strategic orientation}

The Internet is driving a global market-place transformation and companies are required to adapt to customer needs, respond to competitor actions, implement new technologies and thus result in superior performance $[11,20]$. Generally speaking, successful exploitation of information technology (IT) requires having a well defined strategy for IT that links between an organisation's strategy and the technology that supports it. Also, it requires managing widespread ICT applications that are integrated and that facilitate flexible and adaptive behaviour on the part of the firm and its employees.

Marketing and strategic management literature have emphasized on the importance of strategic orientations in helping firms to build dynamic capabilities in fast changing environments. Strategic orientation refers to the philosophy of firms and how firms should interact with external environments to conduct business through a deeply rooted set of values and beliefs [11].

Laforet [15] argues that the extent to which businesses innovate effectively would depend on their ability to plan ahead, to have a clear strategy and to manage strategically, which is reflected in companies being willing to learn as well as to innovate and to take risks. It is worth emphasizing that strategic orientation reflects an outward-looking view of the fit between strategic choices and environment, shaping the organisational responses appropriate for environmental exigencies facing the organisation, it also impacts the way firms acquire, allocate, and utilise resources.

It has been argued that strategic orientation is positioned around the systematic and continuous gathering of information regarding target customer needs, competitor capabilities, and the use of this information to develop new processes and new products or service enduring superior customer value [27]. Taking all the above into account, it can be proposed that:

Hc1: Strategic orientation contributes significantly (and is positively related) to the preliminary adoption of e-commerce.

Hc2: Strategic orientation contributes significantly (and is positively related) to the utilisation of e-commerce.

\subsection{Customer pressure}

Organisations conduct activities within an environmental context. Innovation scholars have posited that the external environment provides opportunities and constraints. External pressure from customers has a critical role in encouraging firms to adopt IT and Internet-based technologies. In fact, customer pressure on firms to adopt e-commerce technologies is considered to be an important category. An innovative customer may force organisations to use and adopt new innovation such as e-commerce and EDI. Hence, we hypothesize that: 
Hd1: Customers pressure contributes significantly (and is positively related) to the preliminary adoption of e-commerce.

$\mathrm{Hd} 2$ : Customers pressure contributes significantly (and is positively related) to the utilisation of e-commerce.

\subsection{Regulatory environment}

E-commerce is influenced also by environmental factors related to regulation in which regulation of ecommerce is very important for the cyberspace market as it can facilitate or inhibit the organisations to adopt e-commerce. The open nature of the Internet brings lot of issues regarding uncertainty, security, lack of transparency, fraud and credit card misuse, which in turn poses unique demands on regulatory support different from other internet technologies such as EDI. Government support to push ecommerce and the existence of e-commerce regulation are important factors that may affect the decision to introduce or adopt e-commerce. This study hypothesizes that an adequate and supportive legal environment should have a positive impact on e-commerce adoption, as follows:

He1: The existence of a regulatory environment contributes significantly (and is positively related) to the preliminary adoption of e-commerce.

He2: The existence of a regulatory environment contributes significantly (and is positively related) to the utilisation of e-commerce.

\subsection{National readiness}

As an application of the Internet, e-commerce depends on information infrastructures and telecommunications for its development [24]. Universally, e-commerce depends on several layers: an infrastructure layer - transportation (roads, air, railroads, etc.); a telecommunications layer (pervasive, modern, secure, and affordable channels); and a software industry to support ecommerce and the opportunity for e-payments [1].

In most developing countries, the IT industry is not sufficiently developed to play supply-push roles, the financial sector is not well established enough to handle electronic transactions, and transportation facilities are poorly developed [19]. However, different firms may perceive the national ecommerce readiness differently and so there may be variations in e-commerce adoption and institutionalization [19]. Based on the above discussion, the following hypotheses seem fitting:

Hf1; National e-readiness contributes significantly (and is positively related) to the preliminary adoption of e-commerce.

Hf2: National e-readiness contributes significantly (and is positively related) to the stabilisation of e-commerce.
A conceptual model was developed to assess ecommerce adoption by organisations in Saudi Arabia as depicted in Figure 1.

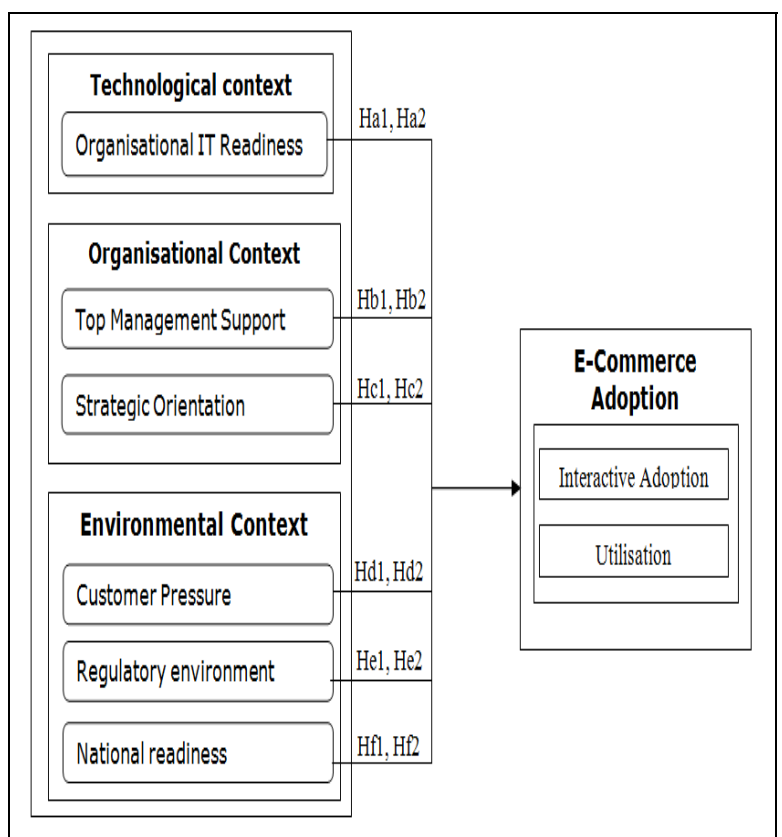

\section{Figure 1. A Contingency Framework for E- commerce Adoption in Saudi Arabia}

\section{Research Methodology}

This section discusses the research methodology used for collecting the data to test the hypotheses. Moreover, definition of the constructs, data collection procedures, the sampling strategy and unit of analysis are described.

\subsection{Survey administration}

A quantitative, cross-sectional survey was used in this research for collecting the data to test the hypotheses. The questionnaire was translated into Arabic, and administrated in the western region known as Hizaj which contains the two holy cities of Makkah (Mecca) and Madena (Medina) and Jeddah. Jeddah is a cosmopolitan city with a rich cultural heritage and many of its residents are pilgrims. Moreover, Jeddah is seen as Saudi Arabia's most liberal city.

Recipients of the questionnaire were chief executive officers (CEOs), general managers, and managing directors of companies selected from the directory of companies distributed by the Council of Saudi Chambers of Commerce and Industry (CSCCI). It was believed that the nature of the research required responses from executives who could make an overall assessment of e-commerce adoption by their firms. 
Direct delivery of the survey questionnaire to companies was preferred as opposed to using online or postal surveys because the postal system in Saudi Arabia is not reliable and the use of online surveys would exclude non-adopters of e-commerce. In all, 450 questionnaires were sent and 202 usable responses were collected, yielding a response rate of $44.88 \%$ percent $(202 / 450)$.

The characteristics of the sample indicate that an overwhelming majority $(65 \%)$ of the respondents were managing directors, CEOs or IS managers. The sample was split between small and medium-sized enterprises (SMEs) with fewer than 100 employees $(32.7 \%)$ and large enterprises with more than 100 employees $(67.3 \%)$. The profile of respondents and their firms is illustrated in Table 1 and Table 2.

Table 1. Descriptive Statistics of

\section{Respondents}

\begin{tabular}{|lcc|}
\hline Gender & Frequency & $\%$ \\
\hline Male & 182 & 90.1 \\
Female & 19 & 9.4 \\
Missing & 1 & 0.5 \\
\hline Age & & \\
\hline 21-29 yrs & 45 & 22.3 \\
30-39 yrs & 68 & 33.7 \\
40-49 yrs & 61 & 30.2 \\
50- 59 yrs & 24 & 11.9 \\
60 or older & 2 & 1.0 \\
Missing & 2 & 1.0 \\
\hline Education & & \\
\hline Less than High School & 3 & 1.5 \\
High School & 20 & 9.9 \\
Trade qualifications & 6 & 3.0 \\
Diploma & 6 & 3.0 \\
Bachelor's & 125 & 61.9 \\
Master's & 36 & 17.8 \\
Doctoral & 6 & 3.0 \\
\hline Position & & \\
\hline President, & 83 & 41.1 \\
Director, CEO & & \\
Information Services (IS) & 49 & 24.3 \\
Manager, Director, & & \\
Planner & & \\
Business Operations & 35 & 17.3 \\
Manager, COO & & \\
\hline Administration/Finance & 35 & \\
Manager, CFO & & \\
\hline
\end{tabular}

\subsection{Measures}

The dependent variable, namely e-commerce adoption, was measured as a dichotomous variable. To operationalise e-commerce adoption, we used the 6-point e-commerce capability indicator developed by Molla and Licker [19], which is relevant to the ecommerce realities of developing countries. Each firm was requested to specify the B2B e-commerce applications used. An organisation was defined as having adopted e-commerce if it had attained the following e-commerce status: (a) an interactive e- commerce status that accepts queries and form entry from users, or (b) a transactive e-commerce status which facilitates transactional trading including online payment and customer service, or (c) an integrated e-commerce status allowing most business transactions to be conducted electronically (Molla and Licker, 2005).

Table 2. Descriptive Statistics of Firms

\begin{tabular}{|c|c|c|}
\hline \multicolumn{3}{|l|}{ Firm's size } \\
\hline 1- 9 employees & 19 & 9.4 \\
\hline $10-25$ employees & 19 & 9.4 \\
\hline $26-100$ employees & 28 & 13.9 \\
\hline 101-200 employees & 36 & 17.8 \\
\hline 201 - 250 employees & 10 & 5.0 \\
\hline 251- 500 employees & 15 & 7.4 \\
\hline $501-1,000$ employees & 19 & 9.4 \\
\hline $1,001-2,500$ employees & 16 & 7.9 \\
\hline More than 2,500 employees & 40 & 19.8 \\
\hline \multicolumn{3}{|l|}{ Industry } \\
\hline Construction and building & 30 & 14.9 \\
\hline $\begin{array}{l}\text { Insurance and financial } \\
\text { services }\end{array}$ & 30 & 14.9 \\
\hline $\begin{array}{l}\text { Computer and electronic } \\
\text { products }\end{array}$ & 28 & 13.9 \\
\hline $\begin{array}{l}\text { Electrical materials and } \\
\text { accessories }\end{array}$ & 19 & 9.4 \\
\hline Food and beverages & 12 & 5.9 \\
\hline Motors and autos & 12 & 5.9 \\
\hline Medical care & 12 & 5.9 \\
\hline Textiles and clothing & 11 & 5.4 \\
\hline $\begin{array}{l}\text { Transportation (Air and } \\
\text { Ground) }\end{array}$ & 10 & 5 \\
\hline $\begin{array}{l}\text { Maintenance and Cleaning } \\
\text { Services }\end{array}$ & 9 & 4.5 \\
\hline Marketing and Advertising & 7 & 3.5 \\
\hline $\begin{array}{l}\text { Tourism and Hospitality } \\
\text { Services }\end{array}$ & 7 & 3.5 \\
\hline Furniture & 6 & 3 \\
\hline Training and consultancy & 5 & 2.5 \\
\hline Publishing and Printing & 4 & 2 \\
\hline
\end{tabular}

It is worth noting that many researchers have considered interactive e-commerce as the preliminary stage of e-commerce adoption [19]. If non-interactive e-commerce (i.e. publishing basic information on the web without any interactivity) was used, the firm is counted as non-adopter. Thus the dependent variable used in this study is dichotomous.

Organisational IT readiness, top management support and strategic orientation were used to capture the organisational context. Organisational IT readiness was measured by the degree to which the firm has sufficient technology infrastructure and IT professionals who possess the knowledge and skills to implement and use internet-related technologies. Moreover, we choose the scale developed by Molla and Licker [19]. It contains 7 items and organisational readiness scale in this study has been shown to have acceptable internal consistency 
reliability with a Cronbach alpha of 0.824 (well above the recommended level of 0.70 ).

Subsequently, top management support was operationalised using the scales developed by Soliman and Janz [29]. It consists of 5 items and these items had acceptable internal consistency reliability, with Cronbach's alpha coefficients of 0.897. Finally, strategic orientation was operationalised by the scale developed Kohli and Jaworski [14], Salavou et al. [26]. It consists of 9 items. The constructs has acceptable internal consistency reliability with a Cronbach's alpha of 0.915 .

The environmental context was captured by three constructs namely, customer pressure (3 items), regulator environment (5 items) and national readiness (9 items). The scale by Al-Qirim [3], Chwelos et al. [7], Kohli and Jaworski [14],Lin and Lin [17], Soliman and Janz [29] was used to examine the three constructs. The three constructs have acceptable internal consistency reliability. Regulatory environment had acceptable internal consistency reliability, with Cronbach's alpha coefficients of 0.924. Customer pressure had Cronbach's alpha of 0.808and finally national readiness with 0.904 Cronbach's alph which was considered well above the recommended level of $0.70[21]$.

It is worth mentioning that some items were modified from their original scales to fit the context of e-commerce adoption in Saudi Arabia and they may differ in wording from those employed for measuring essentially the same constructs by other researchers. Thus, for future empirical research that employs these constructs, it is advisable to use the original source of reference. Respondents were asked to express their degree of agreement on a five-point Likert-type scale ranging from 1 (strongly disagree) to 5 (strongly agree)

\subsection{Validation of the measurement scale}

All the scales were subjected to rigorous analysis in which items were subjected to refinement and the measurements were assessed for their reliability and validity. Validity can be broken down into two subcategories: content and construct validity. Content of measurements is an important area of validation. In fact, the content validity of a construct depends on the extent to which the construct items represent the construct's theme. In this study, the content validity of the research instrument was established through the theoretical literature review and through the extensive process of item selection and refinement in the development of the questionnaire. Also, extensive pilot testing of the instrument ensured that the items were relevant from different groups' perspectives.
Subsequently, factor analysis was used in order to test construct validity and to examine the factor structure of B2B e-commerce adoption antecedent measures. Factorial validity was assessed using a principal component analysis (PCA) with varimax rotation. The PCA is concerned with establishing which components exist within the data and how a particular variable might contribute to that component. Six factors with an Eigenvalue of above 1.0 arose and they were generally consistent with the constructs proposed, representing the themes of technological, organisational and environmental factors.

These six factors all together explained a total of almost $70 \%$ of the variance. Items with factor loadings of less than 0.3 on the selected components were excluded, as were those with loadings greater than 0.30 on other components that had Eigenvalues greater than 1.00. A loading of 0.3 was used because it has been suggested that one should take into account sample size when determining what factor loading is significant [12].

\section{Data analysis and results}

The research hypotheses were analyzed using multiple discriminant function analysis (MDFA), an appropriate technique when the dependent variable is categorical (dichotomous) and the independent variable is interval [12]. The discriminant analysis carried out on the sample was divided into two groups: preliminary adoption (including companies that used interactive e-commerce) and utilisation (including companies which used interactive, transactive or integrated e-commerce). Moreover, differences between the two groups on the several dimensions of the model were tested to identify factors that are significant in differentiating between groups and that are likely to influence adoption of ecommerce.

The results of the discriminant function(s) showed that the overall model was useful for predicting the extent of e-commerce adoption and that the several factors are significant in differentiating between the two groups but not to the same level of significance. These analyses and their results are presented in detail below.

\subsection{Preliminary adoption of e-commerce}

Preliminary e-commerce adoption is operationalized as a dichotomy of whether or not an organisation has attained an interactive e-commerce status. The results of the discriminant analysis together with the descriptive statistics are presented in Table 3.

The MDFA produces a statistically significant function (Wilks' Lambda $(\lambda)=0.809 \quad(\chi 2=27.186$; $\mathrm{df}=19 ; \mathrm{F}=1.093 ; \mathrm{p}<0.100)$ indicating that the model 
is satisfactorily significant in discriminating adopters and non-adopters of e-commerce. Hence, the null hypothesis that, in the population, the means of all discriminant functions in all groups are equal must be rejected. The function correctly classifies 88.8 percent of the businesses in the sample ( 98.5 percent of preliminary e-commerce adoption and 42.9 percent of the transactive e-commerce adoption).

Table 3. Discriminant Analysis of Preliminary Adoption of E-commerce

\begin{tabular}{|l|c|c|c|}
\hline Variable & $\begin{array}{c}\text { Discriminant } \\
\text { loading }\end{array}$ & $\begin{array}{c}\text { F- } \\
\text { Value }\end{array}$ & $\begin{array}{c}\text { P- } \\
\text { Value }\end{array}$ \\
\hline $\begin{array}{l}\text { Organisational } \\
\text { IT readiness }\end{array}$ & $\mathbf{0 . 3 6 9}$ & 4.424 & 0.037 \\
\hline $\begin{array}{l}\text { Top } \\
\text { management } \\
\text { support }\end{array}$ & $\mathbf{0 . 3 2 8}$ & 3.491 & 0.064 \\
\hline $\begin{array}{l}\text { Strategic } \\
\text { orientation }\end{array}$ & 0.173 & 0.971 & 0.326 \\
\hline $\begin{array}{l}\text { Customer } \\
\text { pressure }\end{array}$ & 0.109 & 0.384 & 0.537 \\
\hline $\begin{array}{l}\text { Regulatory } \\
\text { environment }\end{array}$ & $\mathbf{0 . 3 3 6}$ & 4.418 & 0.037 \\
\hline $\begin{array}{l}\text { National } \\
\text { readiness }\end{array}$ & 0.133 & 0.579 & 0.448 \\
\hline
\end{tabular}

In order to determine the relative importance of each of the independent variables in discriminating between the groups, the discriminant loadings and the probabilities for the $\mathrm{f}$ statistics were examined. On the basis of the analysis, organisational IT readiness, management team support and regulatory environment are identified as significant and positive contributors to preliminary e-commerce adoption. Hence, the results fully support three of the six hypotheses (Ha1, Hb1 and $\mathrm{He} 1)$ linking technological, organisational and environmental factors to preliminary e-commerce adoption. Conversely, the remaining factors are found to be poor predictors of the preliminary adoption of ecommerce adoption and did not show loading above the cut-off point.

\subsection{Utilisation of e-commerce}

As discussed earlier, utilisation of e-commerce was evaluated only for organisations that achieved a transactive web presence and integrated web status. Discriminant analysis is again used to test the individual hypotheses relating e-commerce technology characteristics, organisational and environmental factors to the stabilisation of ecommerce (a multichotomous dependent variable of transactive and integrated e-commerce status). The result is summarized in Table 4.
Table 4. Discriminant Analysis of Utilisation of E-commerce

\begin{tabular}{|l|c|c|c|}
\hline Variable & $\begin{array}{c}\text { Discriminant } \\
\text { loading }\end{array}$ & $\begin{array}{c}\text { F- } \\
\text { Value }\end{array}$ & $\begin{array}{c}\text { P- } \\
\text { Value }\end{array}$ \\
\hline $\begin{array}{l}\text { Organisational IT } \\
\text { readiness }\end{array}$ & $\mathbf{0 . 3 1 4}$ & 4.179 & 0.042 \\
\hline $\begin{array}{l}\text { Top management } \\
\text { support }\end{array}$ & $\mathbf{0 . 4 2 6}$ & 7.674 & 0.006 \\
\hline $\begin{array}{l}\text { Strategic } \\
\text { orientation }\end{array}$ & $\mathbf{0 . 4 2 6}$ & 7.681 & 0.006 \\
\hline $\begin{array}{l}\text { Customer } \\
\text { pressure }\end{array}$ & $\mathbf{0 . 3 6 3}$ & 5.559 & 0.019 \\
\hline $\begin{array}{l}\text { Regulatory } \\
\text { environment }\end{array}$ & $\mathbf{0 . 5 5 6}$ & 13.040 & 0.000 \\
\hline $\begin{array}{l}\text { National } \\
\text { readiness }\end{array}$ & 0.294 & 3.648 & 0.058 \\
\hline
\end{tabular}

The independent variables that were most significant to the discriminant function are, in descending order, regulatory environment, strategic orientation, Top management support, customer pressure and organisational IT readiness (Table 4). Therefore, it may be concluded that these variables allow discriminating the utilisation of e-commerce adoption. Subsequently, the results fully support the following hypotheses: $\mathrm{Ha} 2, \mathrm{Hb} 2, \mathrm{Hc} 2, \mathrm{Hd} 2$, and He2.

\section{Discussion of findings}

The goal of this study was to extend understanding of e-commerce adoption in organisations by identifying factors that influence ecommerce adoption and utilisation in Saudi Arabia. A model of e-commerce adoption for organisations in Saudi Arabia was proposed and empirically tested. The findings indicate that the model is sufficiently valid to discriminate preliminary adoption from the degree of utilisation of e-commerce.

In fact, the findings support the argument that effects of different factors may vary depending on the stage of adoption and factors that influence early adopters of a particular innovation may differ significantly from those that impact late adopters [8].

The results in this research demonstrate that organisational readiness can positively impact preliminary adoption and utilisation of e-commerce. This finding is consistent with the previous research [19]. In fact, e-commerce is a complex organisational innovation which implies innovative use of the Internet and related technologies to enable business activities.

According to the analysis results, top management support has significant positive effects on the preliminary adoption and utilisation of e-commerce technology. Intensive e-commerce applications require that top managers continuously provide commitment and support to facilitate e-commerce projects and to overcome the resistance to change 
that is normal in such situations. This is consistent with findings from previous innovation adoption studies [32].

The strategic orientation of the enterprise has been cited by Lefebvre and Lefebvre [16] as an organisational factor that influences the adoption of e-commerce. Consistent with the above assumption, the findings of this study suggest that strategic orientation has a significant positive influence on the utilisation stages of e-commerce technology adoption. Firms with a well-developed strategic rationale in regards to new markets, products and technologies are found to assimilate and routinise ecommerce more extensively for purposes of communication or information, and transaction or collaboration with business partners.

Customer pressure was not significantly related to preliminary adoption of e-commerce, but there was an indication that customer pressure has a significant positive influence $(\mathrm{P}<0.01)$ on the stabilisation of ecommerce. This was expected as Scupola [28] has stated that customer pressure influences the adaptation and evolution of existing approaches to ecommerce development.

Regulatory environment was found to be associated with the preliminary adoption and ecommerce utilisation. This finding is consistent with Molla and Licker's [19] argument that government support is one of the other factors that emerge as discriminating among the two levels of institutionalisation of e-commerce (interactive, transactive, and integrated). In fact, the open nature of the Internet brings with it many issues including uncertainty, lack of transparency, and fraud and credit card misuse, which in turn pose unique demands on regulatory support which are different from other internet technologies such as EDI.

Finally, the findings of this study suggest that national readiness is not significantly $(\mathrm{P}>0.1)$ related to preliminary and utilisation of e-commerce. This is consistent with with the findings of Oxley and Yeung [22] who indicated that although the most salient obstacle to the development of e-commerce in many countries is the lack of necessary physical infrastructure -particularly household access to personal computers and cost-effective telecommunications system, it is important to look beyond these proximate indicators to examine how the institutional environment in a country, particularly with respect to the "rule of law" contributes to (or undermines) confidence in a new technology such as e-commerce and supports the development and investments in new medium.

\subsection{Implications}

Our study has several important implications for managers and policy makers. First, from a managerial standpoint, our empirical findings suggest that as Internet technologies diffuse and become necessities, e-commerce adoption becomes even more significant. This urges top managers to put more effort into assisting firms to develop their own capabilities to integrate e-commerce into the organisation's functionalities through training programs.

Second, e-commerce is a source of strategic advantage and it is widely held that success of ecommerce initiatives is directly affected by company's ability to develop a strategic plan that is positioned around the continuous collection of information regarding target customer needs and competitor capabilities, and the use of this information to create enduring superior customer value. Organisations must review their business strategy that ties e-commerce initiatives to corporate strategy and consequently other business resources in order to create distinctive capabilities for competitive advantage. Generally speaking, successful exploitation of e-commerce requires having a well defined strategy for e-commerce that links between organisation's strategy and the technology that supports it.

Our study also offers implications for policy makers. The consumer readiness factor provides evidence that affordable Internet access and consumers' willingness to shop online can greatly influence firms to adopt e-commerce. Governments, therefore, should establish laws and regulations to protect vulnerable parties and foster trust. Particularly in key issues such as: intellectual property, consumer protection laws, dispute resolution law and compliance and enforcement issues. The study suggests that the government needs to provide specialised courses; seminars and workshops aimed at helping organisations understand the prerequisites for launching their online presence. Moreover, the Council of Saudi Chambers of Commerce and Industry (CSCCI) should have a role in providing technical support and training for professional manpower to meet the labour requirements of businesses to adopt technologies as well as the role of the Saudi commercial banks in providing loans to such enterprises to support their development.

The study findings also suggest that the government should increase awareness and organise technology resource centres to inform and educate managers and owners about the innovative potential of new technologies such as e-commerce. Indeed, a lack of awareness of the use and potential benefits of Internet technologies and IT can hinder the growth of e-commerce.

The absence of appropriate government policies and regulations presents great obstacles to ecommerce adoption in Saudi Arabia. The development literature suggests that countries adopting new technology must have the right 
business environment such as basic infrastructure, appropriate government policies and regulations. Such policies include promotion of computer use, promotion of education generally and for computer professionals in particular, endorsement of low taxes and tariffs on computer imports, and telecommunications liberalization to lower costs [33].

\subsection{Limitation and future research}

This study has certain limitation that can be addressed in future research. First, while the current study was limited to the city of Jeddah (the most cosmopolitan city in the western region of Saudi Arabia), comparative research could target other parts of the country especially in rural areas as opportunities for substantial cultural variations may exist.

Second, instruments used in this study passed various reliability and validity tests, so they could be used in future studies. One future line of research is to use the model in the context of Gulf Cooperation Council (GCC) states (e.g. Kuwait, United Arab Emirates, Qatar, Babrain and Oman) who share some common characteristics.

Third, diffusion research in different disciplines points to the relevance of supply side factors in explaining the process of adoption and diffusion of technological innovations in which it is believed that supplier's marketing activity can influence the probability that a technology will be adopted by an organisation [10]. Further research should also investigate how technology vendors' and consultants' marketing strategies affect organisations' perceptions of e-commerce technologies at different stages of the e-commerce adoption process.

Finally, while this study presents a cross-sectional research, future research should focus on longitudinal studies examining e-commerce implementation process and how e-commerce impacts firm performance, or compare e-commerce adoption in industrialised countries to developing and newly industrialized countries to enrich the findings.

\section{Conclusions}

There is a lack of research coming from developing countries in the Middle East and it is believed that this region has not yet received enough attention from social scientists and organisational analysts [23]. This study gives an insight into the state of e-commerce use among Saudi organisations and provides points of reference for policy makers, government organisations, practitioners and officials engaged in promoting firms' e-commerce adoption. Other nations, in the region can also learn from this study to better understand the potential for ecommerce, assess their readiness and formulate better strategies for e-commerce adoption and use.

\section{Acknowledgements}

The authors wish to acknowledge the Saudi Arabian Ministry of Higher Education for financially supporting this research and the Saudi Arabian Cultural Bureau in the UK for their assistance and support.

\section{References}

[1] S. I. Alfuraih, "E-commerce and E-commerce Fraud in Saudi Arabia: A Case Study", in proceedings of the International Conference on Information Security and Assurance (ISA), 2008

[2] M. B Al-Otaibi, and R.M. Al-Zahrani, "E-commerce adoption in Saudi Arabia: An evaluation of commercial Organizations' web sites", In proceeding of the International Conference on Information Technology in Asia (CITA), 2003, pp.26-31.

[3] N. Al-Qirim "An Empirical Investigation of an ecommerce Adoption-Capability Model in Small Businesses in New Zealand". Electronic Markets, 15 (4), $418-437,2005$

[4] K W. Alrawi, and K. A. Sabry, "E-commerce evolution: a Gulf region review", International Journal of Business Information Systems, 4 (5), 2009, pp.509-526.

[5] S. Al-Somali, R. Gholami and B.T. Clegg, B.T., "An Investigation into the Acceptance of Online Banking in Saudi Arabia”, Technovation, 29 (2), 2009, pp.130-141.

[6] J.E. Austin, Managing in developing countries: strategic analysis and operating techniques. Free Press,New York, 1990.

[7] P. Chwelos I. Benbasat and A. S. Dexter "Empirical test of an EDI adoption model" Information Systems Research, 12 (3), 304-321, 2001.

[8] F. Damanpour, "Innovation Type, Radicalness and the Adoption Process", Communication Research, 15(5), 1988, pp.545-567.

[9] M.S. Eastin, "Diffusion of e-commerce: an analysis of the adoption of four e-commerce activities", Telematics and Informatics, 2002, 19(3), pp. 251-67.

[10] R. Frambach, "An integrated model of organizational adoption and diffusion of innovations". European Journal of Marketing, 27 (5), 22-41, 1993.

[11] H. Gatignon and J. Xuereb "Strategic Orientation of the Firm and New Product Performance. Journal of Marketing Research, 34 (Feb.), 1997, 77-90. 
[12] J. F. Hair, R. E. Anderson, R. L. Tetham and W. C. Black, Multivariate Data Analysis with readings (4th edition), Prentice Hall, Englewood Cliffs, New Jersey, 1995.

[13] C.L. Iacovou, I. Benbasat, and A.S. Dexter, "Electronic data interchange and small organizations: Adoption and Impact of Technology", MIS Quarterly 19 (4), 1995, pp.465-485.

[14] A. Kholi, and B. J. Jaworski "Market-Orientation: The Construct, Research Propositions, and Managerial Implications". Journal of Marketing, 54 (April), 1-18, 1990.

[15] S. Laforet, "Effects of size, market and strategic orientation on innovation in non-high-tech manufacturing SMEs", European Journal of Marketing, 43(1/2),2009, pp. 188-212.

[16] L. A. Lefebvre, E. Lefebvre and J. Harvey, "Intangible Assets as Determinants of Advanced Manufacturing Technology Adoption in SMEs", IEEE Transactions on Engineering Management, 43(3), 1996, pp. 307-22.

[17] H. Lin and S. Lin "Determinants of e-business diffusion: A test of the technology diffusion perspective" Technovation, 28, 135-145, 2008.

[18] MCIT, ICT Indicators in the Kingdom of Saudi Arabia, Ministry of Communications and Information Technology (MCIT), 2009.

[19] A., Molla, A. and P.S. Licker, "Ecommerce adoption in developing countries: a model and instrument", Information and Management, 42, 2005, pp.877-899.

[20] J. C. Narver and S. F. Slater "The effect of a market orientation on business profitability". Journal of Marketing, 54(4), 20-35, 1990.

[21] J. C. Nunnally. Psychometric theory. Vol. 2. New York, McGraw-Hill, 1978.

[22] J. Oxley and B. Yeung, "E-commerce readiness: Institutional environment and international competitiveness", Journal of International Business, 32(4), 2001, pp.705-724.

[23] M. C., Parkerand, T. Castleman, A preliminary MetaAnalysis of SME - eBusiness Journal Publications: Current Trends and Future Research Opportunities Moving Beyond Adoption Factor Studies, 2006, Retrieved May, 12008 from, http://www.collecter2006.unisa.edu.au.

[24] Rodríguez-Ardura, A. Meseguer-Artola, J. VilasecaRequena, "Factors Influencing the Evolution of Electronic Commerce: An Empirical Analysis in a Developed Market Economy", Journal of Theoretical and Applied Electronic Commerce Research, 3(2), 2008,pp.18-29.

[25] E.M Rogers, Diffusion of innovations (4th Ed.), New York: The Free Press, 1995.
[26] H. Salavou, G. Baltas and S. Lioukas, "Organisational innovation in SMEs: the importance of strategic orientation and competitive structure", European Journal of Marketing, 38(9/10), 1091, 2004.

[27] M. Schindehutte, M. H. Morris, A., Kocak, "Understanding market-driving behavior: the role of entrepreneurship", Journal of Small Business Management, 46(1), 2008, pp.4-26.

[28] A. Scupola, "The Adoption of Internet Commerce by SMEs in the South of Italy: An Environmental, Technological and Organizational Perspective", Journal of Global Information Technology Management, 1(6), 2003, 51-71.

[29] K.S. Soliman and B. D. Janz "An exploratory study to identify the critical factors affecting the decision to establish Internet-based inter-organizational information systems" Information \& Management, 41(6), 697-706, 2004.

[30] J. Tan, K. Tyler and A. Manica, "Business- to business adoption of ecommerce in China", Information and Management, 44, 2007, 3321-351.

[31] L.G Tornatzky and M. Fleischer,The Processes of Technological Innovation, Lexington, MA: Lexington Books, 1990.

[32] Y. Wang and X. Shi, X. "E-business assimilation in SMEs of China", International Journal of Electronic Business, 7(5), 2009, pp.512 - 535.

[33] K. Zhu and K. Kraemer, "Post-Adoption Variations in Usage and Value of E-Business by Organizations: CrossCountry Evidence from the Retail Industry", Information Systems Research, 16(1),2005, pp. 61-84.

[34] K. Zhu, K. Kraemer, and S. Xu, "Electronic business adoption by European firms: a cross-country assessment of the facilitators and inhibitors", European Journal of Information Systems, 12 (4), 2003, pp.251-268. 